\title{
SARS-COV-2 in Ophthalmology: Current Evidence and Standards for Clinical Practice
}

\author{
SARS-COV-2 em Oftalmologia: Evidência Atual e \\ Recomendações para a Prática Clínica
}

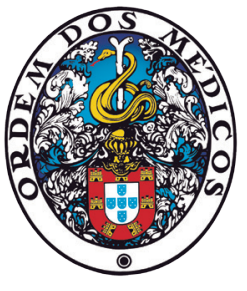

\author{
Sónia TORRES-COSTA ${ }^{1}$, Mário LIMA-FONTES ${ }^{1}$, Fernando FALCÃO-REIS ${ }^{1,2}$, Manuel FALCÃO $\triangle^{1,2}$ \\ Acta Med Port 2020 Sep;33(9):593-600 - https://doi.org/10.20344/amp.14118
}

\section{ABSTRACT}

Introduction: COVID-19 is caused by the coronavirus SARS-CoV-2. Ocular manifestations have been reported including conjunctivitis and retinal changes. Therefore, it is of the utmost importance to clarify eye involvement in COVID-19 in order to help with its diagnosis and to further prevent its transmission. The purpose of this review is to describe the structure and transmission of SARS-CoV-2, reported ocular findings and protection strategies for ophthalmologists.

Material and Methods: Literature search on PubMed for relevant articles using the keywords 'COVID-19', 'coronavirus', and 'SARS-CoV-2' in conjunction with 'ophthalmology' and 'eye'. Moreover, official recommendations of ophthalmological societies were reviewed.

Results: Although the conjunctiva is directly exposed to extraocular pathogens, and the mucosa of the ocular surface and upper respiratory tract are connected by the nasolacrimal duct, the eye is rarely involved in human SARS-CoV-2 infection and the SARS-CoV-2 RNA positive rate by RT-PCR test in tears and conjunctival secretions from patients with COVID-19 is also extremely low.

Discussion: The eye can be affected by SARS-CoV-2, which is supported by some reports of conjunctivitis and retinal changes, but its role in the spread of the disease is still unknown.

Conclusion: Given the current scarce evidence, more research is needed to clarify the relationship between SARS-CoV-2 and the eye. Keywords: Conjunctivitis; Coronavirus Infections; COVID-19; Eye Diseases; Ophthalmology; SARS-COV-2

\section{RESUMO}

Introdução: COVID-19 é o nome atribuído à doença causada pelo novo coronavírus - SARS-CoV-2. Esta infeção rapidamente atingiu uma disseminação mundial, face ao aumento da globalização e adaptação do vírus a ambientes distintos. Foram descritas manifestações oftalmológicas em doentes com COVID-19, nomeadamente, conjuntivite e alterações retinianas. Assim, é fundamental esclarecer o envolvimento ocular na COVID-19, contribuindo para o seu diagnóstico precoce e limitando a sua transmissão. O objetivo desta revisão é descrever a estrutura e o modo de transmissão do SARS-CoV-2, assim como manifestações oculares reportadas e estratégias de proteção para oftalmologistas.

Material e Métodos: Revisão dos artigos relevantes publicados na PubMed usando as palavras-chave 'COVID-19', 'coronavirus' e 'SARS-CoV-2' em associação com as palavras 'ophthalmology' e 'eye'. Além disso, foi feita uma revisão das recomendações oficiais de várias sociedades oftalmológicas a nível mundial.

Resultados: Apesar da conjuntiva estar diretamente exposta a patógenos exógenos, e da mucosa da superfície ocular e do trato respiratório superior estarem conectados pelo canal nasolacrimal, o olho raramente parece ser afetado pelo SARS-CoV-2. A infeção por SARS-CoV-2 e a taxa de positividade para a pesquisa do RNA do SARS-CoV-2 pelo teste de RT-PCR em lágrimas e secreções conjuntivais de pacientes com COVID-19 também são extremamente baixas.

Discussão: O olho pode ser afetado pelo SARS-CoV-2, dada a descrição de casos de conjuntivite e alterações retinianas, mas o seu papel na disseminação da doença ainda é desconhecido.

Conclusão: Dada a escassa evidência atual, são necessários mais estudos para esclarecer a relação entre o SARS-CoV-2 e o globo ocular.

Palavras-chave: Conjuntivite; COVID-19; Infecções por Coronavírus; Oftalmologia; Oftalmopatias; SARS-COV-2

\section{INTRODUCTION}

On the $31^{\text {st }}$ December 2019, the World Health Organization (WHO) was notified of a cluster of 41 cases of unexplained pneumonia happening in Wuhan, Hubei Province, China. Most of the infected people were confirmed to be related to the South China Seafood Market. On the $7^{\text {th }}$ January 2020, the Chinese Centre for Disease Control and Prevention $(C D C)$ isolated through a throat swab the pathogen causative of this disease as a novel type of coronavirus, later called severe acute respiratory syndrome coronavirus 2 (SARS-CoV-2). ${ }^{1,2}$ Based on phylogenomic analysis, it was suggested that this new pathogen was closely re- lated to two coronavirus that were isolated in bats, probably sharing a common ancestor. ${ }^{3}$ The disease associated with SARS-CoV-2 was named coronavirus disease 2019 (COVID-19) and continued to spread in China and progressively all over the world. On the $11^{\text {th }}$ March 2020 , WHO recognized COVID-19 as a pandemic. On the $21^{\text {st }}$ May 2020, COVID-19 was identified in 4893186 people globally, resulting in 323256 deaths. ${ }^{4}$ Currently, there are some reports in the medical literature that identify a direct relationship between SARS-CoV-2 and the eye..$^{2,5-9}$ Therefore, the understanding of ocular manifestations of patients with

1. Department of Ophthalmology. Centro Hospitalar Universitário de São João. Porto. Portugal.

2. Department of Surgery and Physiology. Faculty of Medicine. University of Porto. Porto. Portugal.

$\triangle$ Autor correspondente: Manuel Falcão. falcao@med.up.pt

Recebido: 13 de maio de 2020 - Aceite: 016 de junho de 2020 | Copyright @ Ordem dos Médicos 2020 
COVID-19 by ophthalmologists and others may help in the diagnosis and prevention of disease transmission. The purpose of this review is to describe the SARS-CoV-2 structure, transmission, reported ocular manifestations and protection strategies for ophthalmologists.

\section{MATERIAL AND METHODS}

We performed a literature search on PubMed for relevant articles using the keywords 'COVID-19', 'coronavirus', and 'SARS-CoV-2' in conjunction with 'ophthalmology' and 'eye'. Moreover, official recommendations of ophthalmological societies were systematically reviewed.

\section{Coronavirus family and SARS-CoV-2 structure}

Coronaviruses get their name from the Latin word corona, which means crown and its characteristic structure is due to surface projections on the viral envelope. These positive-sense RNA viruses belong to the subfamily Coronavirinae, in the family Coronaviridae of the order Nidovirales. They have four main subgroups - alpha, beta, gamma, and delta - based on their genomic structure and affect birds and mammals. Coronaviruses may obtain mutations which facilitate the transmission from animal species to humans and this has made them zoonotic pathogens of concern. ${ }^{10,11}$

Up to December 2019, only six different coronaviruses were known to infect humans. Four of these (HCoV-NL63, HCoV-229E, HCoV-OC43 and HKU1) usually caused mild common cold-type symptoms in immunocompetent people whilst the other two have caused notorious epidemics in the past two decades. ${ }^{12}$ In 2002 - 2003, the severe acute respiratory syndrome coronavirus (now termed SARS-CoV-1) was responsible for 774 deaths in 26 countries, affecting more than 8000 people around the world..$^{13}$ Similarly, the Middle East respiratory syndrome coronavirus (MERSCoV) caused a devastating epidemic in 2012, with over 2400 cases reported and a $37 \%$ mortality rate. ${ }^{14}$

\section{SARS-CoV-2 transmission}

While animals are considered the original source, SARS-CoV-2 is believed to spread primarily via person-toperson through larger respiratory droplets, generally above $5 \mu \mathrm{m}$ diameter, which are subject to gravitational forces. ${ }^{15}$ These droplets can be directly inhaled by other people or land on surfaces that others may contact with, where the virus may remain viable from hours to days. ${ }^{13}$ Respiratory particles may be spread while breathing, speaking, coughing or sneezing. Aerosol and fomite transmission of SARSCoV-2 is also plausible and should not be neglected. ${ }^{16}$ Airborne transmission occurs when smaller respiratory particles (generally $<5 \mu \mathrm{m}$ ) circulate in the air for prolonged periods. Viral particles could be absorbed via the respiratory mucosa and potentially across the conjunctivae. ${ }^{15}$ The coronavirus is not currently considered to be an airborne virus unless aerosols are created. In those circumstances, the virus could spread more than 2 meters and additional protective measures should be taken. ${ }^{15}$

Viral RNA has also been found in stool samples from in- fected patients, raising the possibility of a faecal/oral transmission route. ${ }^{17}$ SARS-COV-2 transmission could happen in asymptomatic carrier patients, making the prevention of COVID-19 infection challenging. ${ }^{18}$

The biochemical interactions and the pathogenesis of SARS-CoV-2 are believed to be similar to those of SARSCoV-1. ${ }^{19}$ The spike (S) protein of coronaviruses facilitates viral entry into target cells. Entry depends on binding of the surface unit, S1, of the S protein to a cellular receptor, which facilitates viral attachment to the surface of target cells. In addition, entry requires $S$ protein priming by cellular proteases, which entails spike protein cleavage at the S1/S2 and the S2' site and allows fusion of viral and cellular membranes, a process driven by the $\mathrm{S} 2$ subunit. It was known that SARS-CoV-1 engages angiotensin-converting enzyme 2 (ACE2) as the entry receptor and employs the cellular serine protease TMPRSS2 for $S$ protein priming. ${ }^{19-22} \mathrm{~A}$ recent study with human cell lines reported that SARS-CoV-2 uses the same mechanism to infect cells and that inhibition of TMPRSS2 blocks viral entry. Moreover, sera from convalescent SARS-CoV-1 patients cross-neutralized SARSCoV-2-driven entry. ${ }^{23}$

The most common symptoms of infection are fever, cough and shortness of breath. ${ }^{24}$ Other symptoms include nasal congestion, headache, sore throat, sputum production, fatigue, myalgias, arthralgias, nausea, vomiting, diarrhoea, anosmia and ageusia. ${ }^{25,26}$ Despite this vast array of symptoms, a significant number of infected individuals may be asymptomatic. ${ }^{18}$

\section{Coronavirus family and ocular disease}

It is known that infection by different coronaviruses may lead to ocular involvement.

In 2004, HCoV-NL63 was isolated for the first time from a 7-month-old child with bronchiolitis and conjunctivitis. ${ }^{27}$ The association between this coronavirus and conjunctivitis was corroborated in 2015, in France, by a retrospective study that found an incidence of $17 \%$ for conjunctivitis in a population of children infected with HCoV-NL63. ${ }^{28}$

Ocular involvement has not been reported in MERS-CoV and SARS-CoV-1 infection. Nevertheless, in 2004, a study was conducted to assess the presence of SARS-CoV-1 RNA in tears of infected patients by RT-PCR. Three out of 36 patients tested positive which led to the hypothesis that the conjunctiva could be a direct inoculation site of the virus from infected droplets; other options included migration from the upper respiratory tract through the nasolacrimal duct; or hematogenous infection via the lacrimal gland..$^{29,30}$ A similar assessment was performed in a study published in the same year. However, it failed to demonstrate positive results for SARS-CoV-1 RNA in the tears of the tested patients. ${ }^{31}$

In the current pandemic of SARS-CoV-2, there are already some reports of ocular infection. A member of the Chinese national expert panel on pneumonia developed conjunctivitis during an inspection of Wuhan and later tested positive for the SARS-CoV-2, despite being fully gowned 
with a protective suit and N95 respirator. ${ }^{8}$ This report alerted healthcare professionals in China for the importance of eye protection and resulted in a call for research into ocular infection as a possible alternative route of SARS-CoV-2 transmission.

The WHO-China Joint Mission on COVID-19 estimated the incidence of conjunctival congestion at $0.8 \%$, based on a study in 55924 laboratory confirmed cases. ${ }^{9}$

Two papers studied the presence of SARS-CoV-2 RNA in the ocular surface of infected patients. The first study evaluated 30 infected patients and reported a positive RTPCR test in tears in only one of them, which happened to be the only one who showed signs of conjunctivitis. ${ }^{2}$ The second study analysed a sample of 38 confirmed Covid-19 cases (based on the $5^{\text {th }}$ edition of the National Guideline on Prevention and Control of the Novel Coronavirus Pneumonia published by the National Health Commission of China on February 8, 2020), with 28 patients yielding positive findings for Covid-19 on RT-PCR from nasopharyngeal swabs but only two testing positive for SARS-CoV-2 in their conjunctival swabs. Twelve (31.6\%) patients showed ocular manifestations consistent with conjunctivitis, including conjunctival hyperaemia, chemosis, epiphora, or increased secretions. Conjunctivitis was the first symptom of COVID-19 in one of them. Patients with ocular symptoms were more likely to have higher white blood cell and neutrophil counts and higher levels of procalcitonin, C-reactive protein, and lactate dehydrogenase than patients without ocular symptoms, which could predict a worse prognosis. From the 12 patients with ocular abnormalities, 11 had positive results for SARS-CoV-2 on RT-PCR from nasopharyngeal swabs and only two had positive results for SARS-CoV-2 on RTPCR from conjunctival swabs (and also from nasopharyngeal swabs). ${ }^{7}$ Both studies are compared in Table 1.

Since the human eye has its own renin-angiotensin system, it has been theorized that this new coronavirus could use ACE2 receptors to infect ocular tissues in similarity with the SARS-CoV-1 mechanism of infection of the respiratory tract. Although it was thought that ACE2 was mainly expressed in the posterior tissues of the eye, such as the retina and the retinal pigment epithelium, recently, published evidence demonstrated consistent expression of
ACE2 and TMPRSS2 genes in the conjunctival cells and pterygium cells from patients with pterygium and in corneas of mouses, reintroducing the possibility that the ocular surface could work as an entry point for SARS-CoV-2. ${ }^{32,33}$ This evidence could support the theory that the ocular surface may be a direct infection route to SARS-CoV-2.

One different theory defends that indirect transmission from droplets could occur when viral particles in tears are drained through the nasolacrimal duct into the respiratory tract. $^{34}$

Despite all the described evidence, little is known about the characteristics of COVID-19 conjunctivitis. One paper described the ocular manifestations of a hospitalized patient with confirmed COVID-19 in more detail. Thirteen days after disease onset (with sore throat and diarrhoea being the first symptoms), the patient reported redness, foreign body sensation and tearing in both eyes without blurred vision. At slit lamp examination, bilateral moderate conjunctival injection, watery discharge, inferior palpebral conjunctival follicles and tender palpable preauricular lymph nodes were noted. No subconjunctival haemorrhage or pseudomembranes were observed. No lesions on the corneal or anterior chamber inflammation were detected. Fundoscopy was normal. All ocular symptoms and signs resolved by day 19 of illness. Conjunctival swabs for detection of SARS-CoV-2 RNA were collected on days 13,14, 17 and 19. All the patient's samples tested positive except the last one which correlated with the resolution of the ocular clinical picture. ${ }^{6}$ This is the first report of the duration of COVID-19 associated conjunctivitis. Since there is no knowledge of specific treatments, general supportive measures should be recommended. No evidence was found about ocular surface sequela or corneal involvement or about uveitis linked to COVID-19. In May 2020, the first paper on ocular manifestations other than conjunctivitis in patients with COVID-19 was published. The authors reported retinal findings in 12 patients infected with SARS-CoV-2. In all patients, optical coherence tomography (OCT) showed hyper-reflective lesions at the level of ganglion cell and inner plexiform layers, which were more prominent in the papillomacular bundle in both eyes. Furthermore, four patients presented subtle cotton wool spots and microhaemorrhages along the retinal

Table 1 - Data comparison between Xia et al (2020) and Wu et al (2020) studies about ocular findings in COVID-19

\begin{tabular}{lcc}
\hline Study & Xia et al, 2020 & Wu et al, 2020 \\
\hline Total patients, $n$ & 30 & 38 \\
Severe-type patients, $\mathrm{n}(\%)$ & $9(30 \%)$ & $15(39 \%)$ \\
Age, years (mean \pm SD/median + IQR) & $54.50 \pm 14.17$ & $68(53$ to 76$)$ \\
Male, $\mathrm{n}(\%)$ & $21(70 \%)$ & $25(66 \%)$ \\
Conjunctivitis, $\mathrm{n}(\%)$ & $1(3 \%)$ & $12(32 \%)$ \\
Positive RT-PCR in tears, $\mathrm{n}(\%)$ & $1(3 \%)$ & - \\
Positive RT-PCR in conjunctival swabs, $\mathrm{n}(\%)$ & - & $2(5 \%)$ \\
Positive RT-PCR in sputum, $\mathrm{n}(\%)$ & $29(97 \%)$ & - \\
Positive RT- PCR in nasopharyngeal swabs, $\mathrm{n}(\%)$ & - & $28(74 \%)$ \\
\hline
\end{tabular}

SD: standard deviation; IQR: interquartile range; RT-PCR: reverse-transcription polymerase chain reaction 
arcades. Visual acuity and pupillary reflexes were normal in all eyes, and no symptoms or signs of intraocular inflammation were detected. ${ }^{5}$

Currently, there is increasing evidence that SARS-Cov-2 can involve the nervous system. Recent studies suggested that neurotropic potential is one common feature of the coronavirus family. ${ }^{35}$ Therefore, the infection mechanisms and neurotropism previously found for other coronaviruses like MERS and SARS-CoV could be seen in SARS-CoV-2. ${ }^{36}$ Regarding the clinical features, a previous study in Wuhan, demonstrated that 77 of 214 patients (36\%) hospitalised for COVID-19 developed neurological symptoms or secondary cerebral events. ${ }^{36}$ Other studies reported several categories of central and peripheral neurological disorders in COVID-19 patients. ${ }^{36}$ Reported non-specific and systemic neurological symptoms included headache, myalgia, dizziness, fatigue and hyposmia, hypogeusia and visual dysfunction. ${ }^{24,26,37,38}$ These symptoms range from $30 \%$ to $45.5 \%$, and are more common in severe stages of disease ${ }^{36}$ Other severe neurologic manifestations, recently, reported in COVID-19 patients are encephalopathy, epilepsy, paralysis and consciousness disorders, several categories of cerebrovascular events, such as, intra-cerebral haemorrhage, ischemic stroke, cerebral venous thrombosis and also acute necrotizing encephalopathy, meningitis, encephalitis and GuillainBarré syndrome..$^{36,38,39}$ Hypothesized mechanisms of the neuro-invasion and manifestations on the nervous system include dissemination across the cribriform plate of the ethmoid bone ${ }^{36}$; movement of the virus to the brain via the olfactory bulb ${ }^{40}$ supported by symptoms of hyposmia and hypogeusia reported in COVID-19 patients ${ }^{41,42}$; other possible mechanisms are the hematological pathway and ACE2 receptors. In fact, SARS-CoV-2 has been shown to use the ACE2 receptor as a cellular entry way. ${ }^{36}$ This receptor has been detected in neurons and glial cells, which make it a potential target for SARS-CoV-2. Moreover, SARS-CoV-2 S proteins may interact with ACE2 expressed in the capillary endothelium; this could lead to blood-brain barrier damage and central nervous system (CNS) involvement through the circulatory system. ${ }^{43}$

Due to neuroinvasive and neurotrophic properties, we may hypothesize that SARS-CoV-2 may affect other neuronal structures in the eye including the optic nerve, sub-basal corneal nerve plexus, nerves to the extraocular muscles and to the autonomic system. However, as far as we know, there are no reports of involvement of ocular neuronal structures.

The risks of COVID-19 to ophthalmologists and patients

By the end of March 2020, up to $10 \%$ of the reported cases in China and up to $9 \%$ of all cases in Italy have been identified among healthcare workers. ${ }^{44}$ Curiously, one of the first alarms about COVID-19 was made by Li Wenliang, a Chinese ophthalmologist caring for patients in Wuhan. He died at age 34 years allegedly from the disease. ${ }^{45}$ In fact, ophthalmologists are a risk group due to their proximity to the patient during observation in the slit lamp.
Between the $10^{\text {th }}$ and the $12^{\text {th }}$ March 2020, a survey of ophthalmology practitioners on current COVID-19 guidance at three major UK eye hospitals was performed. It showed a lack of confidence and understanding of COVID-19 Public Health guidance amongst practicing ophthalmologists, along with significant anxiety regarding exposure risk in the ophthalmic setting. ${ }^{46}$ One Italian ophthalmologist reported the dramatic conditions experienced, where adequate personal protective equipment (PPE) was missing. ${ }^{47}$ Adequate protection in healthcare workers, including ophthalmologists, is essential.

The strategies adopted during the pandemic could be divided in three different types of measures:

1. To protect healthcare workers with PPE;

2. To prevent virus spread between patients and healthcare workers;

3. Environmental cleaning and disinfection in healthcare facilities.

\section{(1) Personal protective equipment}

Although, there was some controversy initially regarding the appropriate PPE for ophthalmologists during their clinical practice, several organizations currently agree and recommend the use of masks, long sleeved gowns, goggles and breath shields, and gloves. ${ }^{44}$ Respiratory protection could be subdivided into surgical masks (which protect against infectious agents transmitted by droplets) and facial filtering piece (FFP) respirators (which prevent the wearer from inhaling aerosols). In Europe, FFP respirators are classified in three classes based on filter efficacy and face adhesion: FFP 1, 2 and 3 with filter efficacy of $80 \%, 94 \%$, and $99 \%$, respectively. ${ }^{48}$ In the United States of America, the respirator classification is subdivided in $\mathrm{N}$ (not resistant to oil-aerosols), R (somewhat resistant to oilaerosols) and S (resistant to oil-aerosols) series, and each one of these should have a minimum filter efficiency of $95 \%$, $99 \%$ and $99.97 \%$, respectively. ${ }^{49}$ The American equivalent of the FFP2 is the N95. This respirator blocks at least 95 percent of very small ( 0.3 micron) test particles. Regarding the potential viral spread by asymptomatic COVID-19 carriers, surgical masks are recommended for all patients and healthcare workers. ${ }^{48}$ If in contact with a suspected or confirmed COVID-19 case, healthcare workers should wear, if available, an FFP2 or N95 respirator tested for fitting or, a surgical mask, if no respirator is available. With the exception of aerosol generating procedures, it is unclear whether FFP respirators (class 2 or 3 ) provide better protection than surgical masks against other coronaviruses and respiratory viruses such as influenza. ${ }^{44}$ Therefore, in the event of widespread community transmission leading to shortages of PPE, a rational approach would necessarily prioritize the use of FFP2/3 or N95 respirators for care activities involving a higher perceived risk of transmission, such as during aerosol generating procedures or in intensive care. ${ }^{44}$

Healthcare workers should strictly follow the procedures for putting on (donning) and safely removing (doffing) PPE in the correct sequence. Active assistance during donning 
and doffing will help minimize the risk of accidental contamination. Hands should be washed immediately after the removal of PPE. ${ }^{44}$

(2) Preventing spread of the virus between patients and healthcare professionals

Deferred all non-urgent appointments and surgeries: Many institutions worldwide have recommended delaying all elective and nonurgent appointments and delaying all elective surgical and procedural cases. These appointments and procedures should only be rescheduled upon recommendation of public health authorities. Only emergent and urgent appointments or surgeries should be performed. Regarding the definition of 'elective', although it can vary between ophthalmologists, the American Academy of Ophthalmology (AAO) defines it as an appointment or procedure that can be postponed for two months without substantive risk to the patient's vision, material functioning, or general health. ${ }^{50}$

Staff reorganization: To split the staff into two or three segregated teams, keeping them separated in order to minimize infection risk, as recommended by the Portuguese Society of Ophthalmology. ${ }^{51}$ In particular, colleagues with increased risk (including pregnant women, immunosuppressed people and those with underlying health conditions) should be allocated to a lower risk area or provided with measures to avoid contact with patients. ${ }^{48}$

Teleophthalmology: In the case of routine appointments, the use of telemedicine during the COVID-19 public health crisis could be an alternative. This system allows an effective screening, decreasing patient travel and limiting provider exposure. In some cases, telehealth information may be enough to make treatment recommendations. In other cases, telemedicine may allow ophthalmologists to suspect or even identify a specific ocular disease, such as corneal disease, retinal or neuro-ophthalmological symptoms, and guide the patient for observation by subspeciality trained ophthalmologists. ${ }^{50}$

Patient triage: Patients who come to an appointment should answer a survey, at the main hospital entrance, about the presence of risks factors or symptoms suggestive of COVID-19: (1) fever, acute onset or persistent or continuous cough, hoarseness, sore throat, shortness of breath, wheezing, anosmia, headache, myalgia, gastrointestinal symptoms; (2) symptoms of conjunctivitis including red eye, pruritus, foreign body sensation, watering; (3) close contact with suspected or confirmed COVID-19. Patients that fulfil any criteria, should be sent home, and recommended to stay in isolation 14 days until symptoms resolve. At the hospital main entrance, temperature should be measured, hands disinfected, and a surgical face mask should be given to the patient. Only the patient can enter the hospital. Family members or friends must wait at the main entrance. ${ }^{48}$ In special situations in which a caregiver is necessary, the caregiver should also disinfect his hands and wear a mask.

Ophthalmology waiting room: Advise seated patients to remain at least two meters apart from one another. The healthcare workers should regularly disinfect surfaces.

During ophthalmological examination: Ophthalmologists should wear PPE, as described previously. The use of slit-lamp barriers is recommended. If possible, all patients should wear masks during examination and ophthalmologists should inform their patients not to speak during the slit-lamp observation. The time required to observe the patient should be minimized. Only essential procedures should be performed. Special tests such as visual field test, optical coherence tomography, corneal topography, ultrasound, should only be requested when critical to making a clinical decision.

Hand hygiene: The WHO recommends washing hands regularly with alcoholic gel solutions for both healthcare workers and patients.

(3) Environmental cleaning and equipment disinfection recommendations

Rooms and instruments should be thoroughly disinfected after each patient observation. Healthcare workers should wear disposable gloves when cleaning and disinfecting surfaces and discard the gloves after use. Slit lamps, including controls and accompanying breath shields, should be disinfected, immediately after each patient evaluation.

According to WHO recommendations and current practice of several centres, all shared equipment having contact with ocular tissues, such as slit lamps and b-scan probes, should be disinfected with $70 \%$ ethyl alcohol after the clinical examination. ${ }^{3,52}$ The current CDC recommendations for disinfectants specific to COVID-19 include diluted household bleach 5 tablespoons bleach per gallon/per 3.8 litres of water and alcohol solutions with at least $70 \%$ alcohol. ${ }^{50}$ Other common United Stated Environment Protection Agency (EPA) registered disinfectants currently recommended for use against SARS-CoV-2 can be seen in the EPA recommendations. ${ }^{53}$

SARS-CoV-2 is an enveloped virus, unlike adenoviruses that are much more resistant to alcohol. Therefore, $70 \%$ alcohol solutions should be effective for disinfecting tonometer tips. ${ }^{50}$ However, considering the risk of conjunctival transmission, tonometry should be limited to cases strictly necessary. In that case, AAO recommends single-use, disposable tonometer tips or preferably using the retropulsion tonometer with disposable nozzles. ${ }^{50}$ Non-contact tonometry is a potential source of microaerosols, and therefore, it is prudent to suspend its use. ${ }^{50}$

\section{Therapy adjustment in ocular inflammatory disease}

According to the recommendations of the Portuguese Group of Ocular Inflammation and in line with the International Uveitis Study Group (IUSG), the International Ocular Inflammation Society (IOIS) and the Ocular Foster Inflammation Society (FOIS), the following measures are recommended in patients with known ophthalmological inflammatory disease: to individualize the therapeutic strategy on a case-by-case basis, depending on the intraocular inflammatory activity, involvement of the posterior segment, 
chronicity, risk of functional loss and state of the other eye; to prefer topical therapy and/or local corticosteroid therapy instead of systemic immunomodulatory agents. ${ }^{54}$ In cases of increased risk of secondary ocular hypertension, consider prescription of hypotensive topical eye therapy after local treatment. Local corticosteroid therapy has not been associated with an increased risk of COVID-19 infection, according to the available evidence. ${ }^{54}$ Additional recommendations concerning non-infectious uveitis under immunomodulatory treatment can be found in Table 2.

\section{Chloroquine and hydroxychloroquine as treatment of COVID-19: the role of the ophthalmologist}

Chloroquine (CQ) and hydroxychloroquine (HCQ) were approved as treatment for COVID-19 by the US Food and Drug Administration (FDA) based on limited in-vitro and anecdotal clinical data and is being used as off-label in many countries. ${ }^{55-58}$ Treatment has been authorized despite warnings from scientific advisers about the lack of randomized controlled trials supporting these drugs' safety and efficacy in this population. ${ }^{55}$

An observational study of 1376 patients with COVID-19 who had been admitted to a large medical centre in New York City demonstrated that $\mathrm{HCQ}$ administration was not associated with neither a greatly lowered or increased risk of intubation or death. ${ }^{59}$

The lack of observed benefit of HCQ associated with inhospital mortality, following adjustment for pre-existing disease and severity of illness on admission, is consistent with recently reported data from other observational studies. ${ }^{60}$ Regarding the dose and duration of treatment, there are some variations. For instance, in China, a 10-day course of $500 \mathrm{mg} \mathrm{CQ}$ twice daily, or $400 \mathrm{mg} \mathrm{HCQ}$ four times daily is being used. ${ }^{61}$ In France, initially, 600 mg/day of HCQ for 10 days was used. ${ }^{56}$ In Portugal, although the HCQ as treatment for COVID-19 has been suspended, at the beginning of this pandemic, HCQ was prescribed as $400 \mathrm{mg}$ twice daily for one day, followed by $200 \mathrm{mg}$ twice daily for five or 10 days according to the patient's disease course. ${ }^{62}$

Although $\mathrm{CQ}$ and $\mathrm{HCQ}$ are still used in many countries, taking into account the latest data reported by recent studies that suggested the absence of benefit or even an increased risk of mortality associated with $\mathrm{HCQ}$, at the end of May 2020, several European countries, namely France, Belgium, Italy and Portugal have suspended the use of $\mathrm{HCQ}$ as treatment for COVID-19. ${ }^{63,64}$

The AAO recommended a maximum daily $\mathrm{HCQ}$ use of $\leq 5.0 \mathrm{mg} / \mathrm{kg}$ of real weight, with risk of toxicity being

Table 2 - Recommendations for evaluation and therapy management in non-infectious uveitis on immunomodulatory therapy during COVID-19 pandemics based on Portuguese Group of Ocular Inflammation

\section{Non-infectious uveitis previously on immunomodulatory therapy}

\section{Patients are under higher infectious risk if:}

- Under oral prednisolone $>20 \mathrm{mg} / \mathrm{day}$ (or $0.5 \mathrm{mg} / \mathrm{kg} /$ day) for more than 4 weeks,

- Under two or more drugs,

- Immunosuppressants associated with another co-morbidity,

- Under oral prednisolone $>5 \mathrm{mg} /$ day associated with another immunomodulatory drug

- Administration of cyclophosphamide or rituximab in the last 6 months.

\section{How to manage immunomodulatory therapy}

- In patients undergoing dose titration, if possible, interrupt dose reduction and maintain the minimum dose previously effective ideally until the disappearance of pandemic risk and normalization of evaluation conditions for patients;

- Avoid switching or starting new immunomodulatory treatments until that the pandemic is controlled.

\section{Analytical study}

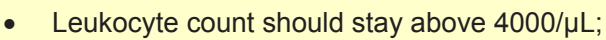

- Repeat an analytical study to monitor pharmacological toxicity whenever necessary, spacing harvest intervals in patients without evidence of toxicity, with leukocytes $>4000 / \mu \mathrm{L}$ and without recent increase in dose drugs;

- Prioritize, if possible, harvests in a location close to the patient.

\section{Clinic compatible with COVID-19 infection}

- Immunomodulatory therapy can theoretically compromise the response immune system in the early stages of COVID-19. On the other hand, a beneficial effect on the eventual prevention and treatment of 'Cytokine storm syndrome' that characterizes stage III of COVID-19 (with emphasis on interferon and tocilizumab) could be seen.

- Asymptomatic patients suspected of having a COVID-19 infection:

- Blood count should be monitored;

- To discuss with the doctor responsible for monitoring of SARS-CoV-2 infection the need to reduce or suspension of immunomodulatory therapy;

Testing will be desirable screening for SARS-CoV-2 infection;

- Symptomatic patients with confirmed COVID-19 infection:

- Temporary interruption of immunomodulatory treatment, (conventional or biological) until complete recovery of COVID-19 infection;

- In systemic corticotherapy, the minimum time required for tapering should be guaranteed;

- The maintenance option of interferon or tocilizumab should be mandatorily discussed with the doctor responsible for the treatment of COVID-19 infection. 
dependent on daily dose and duration of use. ${ }^{65}$ With this dosage, retinopathy is rarely seen before 10 or more years of treatment. Nevertheless, in order to treat COVID- 19, the dosages used are higher than those recommended by the AAO, even if for a short period of time. ${ }^{61}$ Therefore, Marmor MF suggested that ophthalmic screening is not necessary for COVID-19 patients who take CQ or HCQ for less than two weeks as anti-viral therapy, because the probability of retinal damage is remarkably low even with high dosages. ${ }^{61}$ Besides, in a time of pandemic with world-wide shortages of medical personnel and equipment, the performance of questionable screening tests would be counterproductive. ${ }^{61}$ Therefore, ophthalmologists should reassure physicians and the public that retinopathy is not a serious concern regarding CQ or HCQ usage for COVID-19. ${ }^{61}$

\section{CONCLUSION}

The eye can be affected by this new disease, which is supported by some reports of conjunctivitis in patients with
COVID-19. Moreover, it can be the first organ to show signs of infection, but the frequency of this first manifestation is unknown. The ocular surface can work as an entry point for the virus and the tears can promote the migration of the virus to the respiratory system through the nasolacrimal duct; tears may possibly be a source of infection to other individuals. Given the current scarce evidence, more research is needed to clarify the relationship between SARS-CoV-2 and the eye. Until then, ophthalmologists should continue to use all the recommended protection measures to prevent the possible transmission of SARS-CoV-2 through ocular tissue.

\section{CONFLICTS OF INTEREST}

None of the authors has conflict of interest with this submission.

\section{FUNDING SOURCES}

No financial support was received for this submission.

\section{REFERENCES}

1. Lu H, Stratton CW, Tang YW. Outbreak of pneumonia of unknown etiology in Wuhan, China: The mystery and the miracle. J Med Virol. 2020;92:401-2

2. Xia J, Tong J, Liu M, Shen Y, Guo D. Evaluation of coronavirus in tears and conjunctival secretions of patients with SARS-CoV-2 infection. J Med Virol. 2020.;92:589-94..

3. Zhang L, Shen FM, Chen F, Lin Z. Origin and evolution of the 2019 novel coronavirus. Clin Infect Dis. 2020 (in press). doi: 10.1093/cid/ciaa112.

4. World Health Organization. Coronavirus disease 2019 (COVID-19) Situation Report - 122. 2020. [accessed 2020 May 30]. Available from: https://www.who.int/docs/default-source/coronaviruse/situationreports/20200521-covid-19-sitrep-122. pdf?sfvrsn=24f20e05 2:1-17.

5. Marinho PM, Marcos AA, Romano AC, Nascimento $H$, Belfort R Jr. Retinal findings in patients with COVID-19. Lancet. 2020;395:1610.

6. Chen L, Liu M, Zhang Z, Qiao K, Huang T, Chen M, et al. Ocular manifestations of a hospitalised patient with confirmed 2019 novel coronavirus disease. $\mathrm{Br} \mathrm{J}$ Ophthalmol. 2020 (in press). doi: 10.1136/ bjophthalmol-2020-316304.

7. Wu P, Duan F, Luo C, Liu Q, Qu X, Liang L, et al. Characteristics of ocular findings of patients with coronavirus disease 2019 (COVID-19) in Hubei Province, China. JAMA Ophthalmol. 2020;138:575-8.

8. Lu CW, Liu XF, Jia ZF. 2019-nCoV transmission through the ocular surface must not be ignored. Lancet. 2020;395:e39.

9. Spreading SARS-CoV-2 through ocular fluids. 2020. [accessed 2020 Apr 10]. Available from: https://www.cebm.net/covid-19/spreading-sarscov-2-through-ocular-fluids/.

10. Cui J, Li F, Shi ZL. Origin and evolution of pathogenic coronaviruses. Nat Rev Microbiol. 2019;17:181-92.

11. Zhou P, Fan $H$, Lan $T$, Yang $X L$, Shi WF, Zhang $W$, et al. Fatal swine acute diarrhoea syndrome caused by an HKU2-related coronavirus of bat origin. Nature. 2018;556:255-8.

12. Rabi FA, Al Zoubi MS, Kasasbeh GA, Salameh DM, Al-Nasser AD. SARS-CoV-2 and coronavirus disease 2019: what we know so far. Pathogens. 2020;9.

13. Peiris JS, Yuen KY, Osterhaus AD, Stöhr K. The severe acute respiratory syndrome. N Engl J Med. 2003;349:2431-41.

14. Marie EK, Holly MB, Claire MM, Susan IG, John TW. Middle East respiratory syndrome coronavirus transmission. Emerg Infect Dis. 2020;26:191.

15. Cook TM. Personal protective equipment during the COVID-19 pandemic - a narrative review. Anaesthesia. 2020; 75:920-7..

16. van Doremalen N, Bushmaker T, Morris DH, Holbrook MG, Gamble A, Williamson BN, et al. Aerosol and surface stability of SARS-CoV-2 as compared with SARS-CoV-1. N Engl J Med. 2020; 382:1564-7..

17. Holshue ML, DeBolt C, Lindquist S, Lofy KH, Wiesman J, Bruce H, et al.
First case of 2019 novel coronavirus in the United States. N Engl J Med. 2020;382:929-36.

18. Bai Y, Yao L, Wei T, Tian F, Jin DY, Chen L, et al. Presumed asymptomatic carrier transmission of COVID-19. JAMA. 2020; 323:1406-7.

19. Li W, Moore MJ, Vasilieva N, Sui J, Wong SK, Berne MA, et al. Angiotensin-converting enzyme 2 is a functional receptor for the SARS coronavirus. Nature. 2003;426:450-4.

20. Glowacka I, Bertram S, Müller MA, Allen P, Soilleux E, Pfefferle S, et al. Evidence that TMPRSS2 activates the severe acute respiratory syndrome coronavirus spike protein for membrane fusion and reduces viral control by the humoral immune response. J Virol. 2011;85:4122-34.

21. Matsuyama S, Nagata N, Shirato K, Kawase M, Takeda M, Taguchi F. Efficient activation of the severe acute respiratory syndrome coronavirus spike protein by the transmembrane protease TMPRSS2. J Virol. 2010;84:12658-64.

22. Shulla A, Heald-Sargent T, Subramanya G, Zhao J, Perlman S, Gallagher T. A transmembrane serine protease is linked to the severe acute respiratory syndrome coronavirus receptor and activates virus entry. J Virol. 2011;85:873-82.

23. Hoffmann M, Kleine-Weber H, Schroeder S, Krüger N, Herrler T, Erichsen $\mathrm{S}$, et al. SARS-CoV-2 cell entry depends on ACE2 and TMPRSS2 and is blocked by a clinically proven protease inhibitor. Cell. 2020;181:271-80. e8.

24. Huang C, Wang Y, Li X, Ren L, Zhao J, Hu Y, et al. Clinical features of patients infected with 2019 novel coronavirus in Wuhan, China. Lancet. 2020;395:497-506.

25. Guan WJ, Ni ZY, Hu Y, Liang WH, Ou CQ, He JX, et al. Clinical characteristics of coronavirus disease 2019 in China. N Engl J Med. 2020; 382:1708-20.

26. Vaira LA, Salzano G, Deiana G, De Riu G. Anosmia and ageusia: common findings in COVID-19 patients. Laryngoscope. 2020;13:1787.

27. van der Hoek L, Pyrc K, Jebbink MF, Vermeulen-Oost W, Berkhout RJ, Wolthers KC, et al. Identification of a new human coronavirus. Nat Med. 2004;10:368-73.

28. Astrid V, Thomas $M$, Julia $D$, Lia van der $H$, Stéphanie $G$, Joëlle $P$, et al. Human coronavirus NL63, France. Emerg Infect Dis. 2005;11:1225.

29. Loon SC, Teoh SC, Oon LL, Se-Thoe SY, Ling AE, Leo YS, et al. The severe acute respiratory syndrome coronavirus in tears. $\mathrm{Br} J$ Ophthalmol. 2004;88:861.

30. Seah I, Agrawal R. Can the coronavirus disease 2019 (COVID-19) affect the eyes? A review of coronaviruses and ocular implications in humans and animals. Ocul Immunol Inflamm. 2020;28:391-5.

31. Chan WM, Yuen KS, Fan DS, Lam DS, Chan PK, Sung JJ. Tears and conjunctival scrapings for coronavirus in patients with SARS. Br J Ophthalmol. 2004;88:968. 
32. Ma D, Chen CB, Jhanji V, Xu C, Yuan XL, Liang JJ, et al. Expression of SARS-CoV-2 receptor ACE2 and TMPRSS2 in human primary conjunctival and pterygium cell lines and in mouse cornea. Eye. 2020 (in press). doi:10.1038/s41433-020-0939-4.

33. Choudhary R, Kapoor MS, Singh A, Bodakhe SH. Therapeutic targets of renin-angiotensin system in ocular disorders. J Curr Ophthalmol. 2017;29:7-16.

34. Liu Z, Sun CB. Conjunctiva is not a preferred gateway of entry for SARS-CoV-2 to infect respiratory tract. J Med Virol. 2020 (in press). doi: 10.1002/jmv.25859.

35. Yuan Y, Cao D, Zhang Y, Ma J, Qi J, Wang Q, et al. Cryo-EM structures of MERS-CoV and SARS-CoV spike glycoproteins reveal the dynamic receptor binding domains. Nat Commun. 2017;8:15092.

36. Abboud $\mathrm{H}$, Abboud FZ, Kharbouch $\mathrm{H}$, Arkha $\mathrm{Y}$, Abbadi NE, Ouahabi AE. COVID-19 and SARS-Cov-2 infection: pathophysiology and clinical effects on the nervous system. World Neurosurg. 2020; 140:49-53..

37. Xu XW, Wu XX, Jiang XG, Xu KJ, Ying LJ, Ma CL, et al. Clinical findings in a group of patients infected with the 2019 novel coronavirus (SARSCov-2) outside of Wuhan, China: retrospective case series. BMJ. 2020;368:m606.

38. Romero-Sánchez CM, Díaz-Maroto I, Fernández-Díaz E, SánchezLarsen Á, Layos-Romero A, García-García J, et al. Neurologic manifestations in hospitalized patients with COVID-19: The ALBACOVID registry. Neurology. 2020 (in press). doi: 10.1212/ wnl.0000000000009937.

39. Lascano AM, Epiney JB, Coen M, Serratrice J, Bernard-Valnet R, Lalive $\mathrm{PH}$, et al. SARS-CoV-2 and Guillain-Barré syndrome: AIDP variant with favorable outcome. Eur J Neurol. 2020 (in press). doi: 10.1111/ ene. 14368 .

40. Swanson PA 2nd, McGavern DB. Viral diseases of the central nervous system. Current opinion in virology. 2015;11:44-54.

41. Hwang CS. Olfactory neuropathy in severe acute respiratory syndrome: report of a case. Acta Neurol Taiwan. 2006;15:26-8.

42. Conde Cardona G, Quintana Pájaro LD, Quintero Marzola ID, Ramos Villegas Y, Moscote Salazar LR. Neurotropism of SARS-CoV 2: mechanisms and manifestations. J Neurol Sci. 2020;412:116824.

43. Baig AM, Khaleeq A, Ali U, Syeda H. Evidence of the COVID-19 virus targeting the CNS: tissue distribution, host-virus interaction, and proposed neurotropic mechanisms. ACS Chem Neurosci. 2020;11:9958.

44. European Centre for Disease Prevention and Control. Infection prevention and control and preparedness for COVID-19 in healthcare settings - second update 31 march. 2020. [accessed 2020 May 01 ]. Available from: https://www.ecdc.europa.eu/sites/default/files/ documents/Infection-prevention-control-for-the-care-of-patients-with2019-nCoV-healthcare-settings_update-31-March-2020.pdf.

45. Sommer A. Humans, viruses, and the eye-an early report from the COVID-19 front kine. JAMA Ophthalmol. 2020; 138:578-9.

46. Minocha A, Sim SY, Than J, Vakros G. Survey of ophthalmology practitioners in A\&E on current COVID-19 guidance at three major UK eye hospitals. Eye. 2020 (in press). doi: 10.1038/s41433-020-0857-5.

47. Aleci C. COVID-19 and opthalmologists. Neuro Ophthalmol Vis Neurosci. 2020;5:1-1.

48. Romano MR, Montericcio A, Montalbano C, Raimondi R, Allegrini D, Ricciardelli G, et al. Facing COVID-19 in Ophthalmology department. Curr Eye Res. 2020;45:653-8.

49. Centers for Disease Control and Prevention. NIOSH-Approved particulate filtering facepiece respirators. 2020. [accessed $2020 \mathrm{Apr}$ 11]. Available from: https://www.cdc.gov/niosh/nppt//topics/respirators/ disp part/default.html

50. American Academy of Ophthalmology. Important coronavirus updates for ophthalmologists. 2020. [accessed 2020 Apr 9]. Available from: https://www.aao.org/headline/alert-important-coronavirus-context.

51. Sociedade Portuguesa de Oftalmologia, Colégio de Oftalmologia Recomendações do Colégio de Oftalmologia e da SPO perante a situação de risco epidemiológico de infecção por covid-19. Oftalmologia. 2020. [accessed 2020 May 30]. Available from: https://revistas.rcaap.pt/ index.php/oftalmologia/article/view/19831.

52. Jun IS, Hui KK, Songbo PZ. Perspectives on coronavirus disease 2019 control measures for ophthalmology clinics based on a Singapore center experience. JAMA Ophthalmol. 2020;138:435-6.

53. List N: Disinfectants for use against SARS-CoV-2. United States Environment Protection Agency. [accessed 2020 Apr 9]. Available from: https://www.epa.gov/pesticide-registration/list-n-disinfectants-useagainst-sars-cov-2.

54. Grupo Português de Inflamação Ocular. Orientações para a abordagem do doente com inflamação ocular em contexto da pandemia covid-19. Oftalmologia. 2020. [accessed 2020 May 1]. Available from: https:// revistas.rcaap.pt/index.php/oftalmologia/article/view/19830.

55. Lenzer J. Covid-19: US gives emergency approval to hydroxychloroquine despite lack of evidence. BMJ. 2020;369:m1335.

56. Gautret $\mathrm{P}$, Lagier JC, Parola P, Hoang VT, Meddeb L, Mailhe M, et al Hydroxychloroquine and azithromycin as a treatment of COVID-19: results of an open-label non-randomized clinical trial. Int J Antimicrob Agents. 2020 (in press). doi: 10.1016/j.ijantimicag.2020.105949:105949.

57. Perinel S, Launay M, Botelho-Nevers E, Diconne E, Louf-Durier A Lachand $\mathrm{R}$, et al. Towards optimization of hydroxychloroquine dosing in intensive care unit COVID-19 patients. Clin Infect Dis. 2020 (in press). doi: $10.1093 / \mathrm{cid} / \mathrm{ciaa} 394$.

58. Gao J, Tian Z, Yang X. Breakthrough: chloroquine phosphate has shown apparent efficacy in treatment of COVID-19 associated pneumonia in clinical studies. Biosci Trends. 2020;14:72-3.

59. Geleris J, Sun Y, Platt J, Zucker J, Baldwin M, Hripcsak G, et al Observational study of hydroxychloroquine in hospitalized patients with covid-19. N Engl J Med. 2020 (in press). doi: 10.1056/NEJMoa2012410.

60. Rosenberg ES, Dufort EM, Udo T, Wilberschied LA, Kumar J, Tesoriero $\mathrm{J}$, et al. Association of treatment with hydroxychloroquine or azithromycin with in-hospital mortality in patients with COVID-19 in New York state. JAMA. 2020 (in press). doi: 10.1001/jama.2020.8630.

61. Marmor MF. COVID-19 and chloroquine/hydroxychloroquine: is there ophthalmological concern? Am J Ophthalmol. 2020;213:A3-4.

62. Serviço de Doenças Infeciosas do Centro Hospitalar de São João. Protocolo do CHUSJ de tratamento antivírico da COVID19. Porto: Centro Hospitalar Universitário de São João; 2020.

63. Marmor MF, Kellner U, Lai TY, Melles RB, Mieler WF. Recommendations on screening for chloroquine and hydroxychloroquine retinopathy (2016 revision). Ophthalmology. 2016;123:1386-94.

64. INFARMED. Infarmed e DGS recomendam suspensão do uso de hidroxicloroquina em doentes com COVID-19. 2020. [acessed 2020 jun 21]. Available from: https://www.infarmed.pt/documents/15786/3584909/ Comunicado+de+Imprensa+-+Infarmed+e+DGS+recomendam+suspe $\mathrm{ns} \% \mathrm{C} 3 \% \mathrm{~A} 3 \mathrm{o}+\mathrm{do}+$ uso + de + hidroxicloroquina+em+doentes+com $+\mathrm{COV}$ ID-19/1254453b-5943-1668-12cc-828e2bee3ab1:1.

65. Global report: EU countries block hydroxychloroquine, South Korea fears new spike. The Guardian, 2020. [accessed 2020 june 21]. Available from: https://www.theguardian.com/world/2020/may/27/global-reporteuropean-countries-act-against-use-hydroxychloroquine-infections-upsouth-koreaat. 